\title{
VIBURNINE, A MACROCYCLIC SPERMIDINE ALKALOID FROM VIBURNUM RHYTIDOPHYLLUM
}

\author{
O.M. Abdallah and Z.Z. Ibraheim
}

Department of Pharmacognosy, Faculty of Pharmacy, Assiut University, Assiut, Egypt

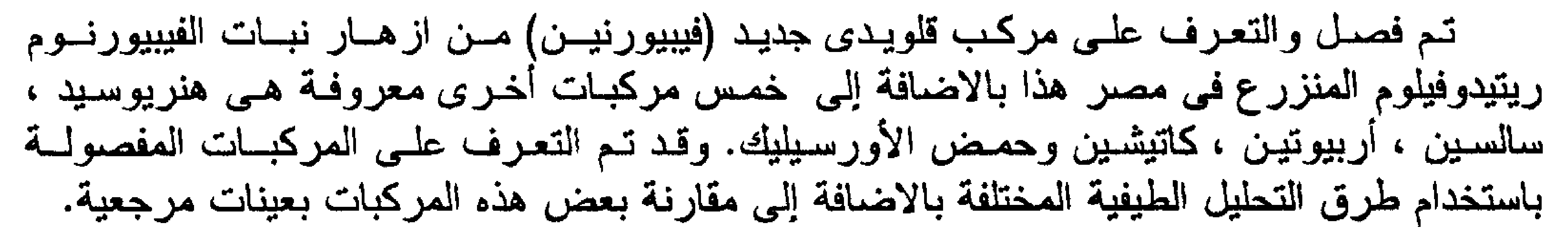

A new macrocyclic spermidine alkaloid; viburnine was isolated from the flowers of Viburnum rhytidophyllum Hessel cultivated in Egypt together with five known compounds; henryoside, salicin, arbutin, catechin and ursolic acid. The identification of the isolated compounds was carried out by spectral analysis and / or comparison with authentic samples.

\section{INTRODUCTION}

The members of the genus Viburnum (F. Caprifoliaceae) are attractive ornamental shrubs growing in North and Central America, North Africa and East Asia. V. rhytidophyllum Hessel is an ornamental shrub cultivated in Egypt. The plants of the genus Viburnum have many folkloric medicinal uses as antispasmodic, anthelmintic for children, a remedy for tapeworm in animals, emmenagogue and as menorrhagia as well as in post partum haemorrhage $e^{1-5}$.

A number of coumarins, phenolic glycosides, iridoides, triterpenes and other constituents were isolated from some plants belonging to the genus Viburnum ${ }^{6.18}$. However, there is no report traced on the presence of alkaloids in this genus.

We report herein detailed studies on the isolation and structural elucidation of a new alkaloid.

\section{EXPERIMENTAL}

General experimental procedure

Melting Points (uncorr.) were determined by Koffler hot stage microscope, type (ESP, Boetius M.) ${ }^{1} \mathrm{H}-\mathrm{NMR}(90 \mathrm{MHz})$ and ${ }^{13} \mathrm{C}-\mathrm{NMR}$
(22.4 MHz) spectra were recorded by Bruker instrument in $\mathrm{CDCl}_{3}$ and $\mathrm{CD}_{3} \mathrm{OD}$ using TMS as internal standard. IR spectra were determined using Unicam Sp-1025 infra red Spectrometer in $\mathrm{KBr}$. UV spectra are determined in Unicam Sp-1750 ultra-violet Spectrometer. MS were recorded at $70 \mathrm{ev}$ using direct inlet system with high resolution MS-50 Kratos A.E.I. Column chromatography was performed on Silica gel (70-230, E. Merck). while TLC using silica-gel $\mathrm{G}_{60}$ (E. Merck) and PC using whatman paper No.1 The following solvent systems were used

$$
\begin{aligned}
& \text { I- } \mathrm{CHCl}_{3}-\mathrm{MeOH} \\
& \text { II- } \mathrm{CHCl}_{3}-\mathrm{MeOH}-\mathrm{H}_{2} \mathrm{O} \\
& \text { III- } \mathrm{CHCl}_{3}-\mathrm{MeOH}-\mathrm{H}_{2} \mathrm{O} \\
& \text { IV- Butanol-HOAc- } \mathrm{H}_{2} \mathrm{O}
\end{aligned}
$$

$10 \% \mathrm{H}_{2} \mathrm{SO}_{4}$ and Dragendorff's reagent are used for locating the spots over chromatoplates.

\section{Plant material}

The material used was obtained from cultivated plants collected from El-Orman Garden, Cairo. The identity of the plant was confirmed by Prof. Dr. N. El-Hadidi, Faculty of Science, Cairo University. A voucher sample is kept in the Faculty of Pharmacy, Assiut University. 


\section{Extraction and isolation}

Air-dried powdered flowers $(1.5 \mathrm{~kg})$ was defatted with petrol $\left(60-80^{\circ}, 3\right.$ liters $\left.\times 4\right)$ followed by exhaustive extraction with $\mathrm{MeOH}(3$ liters $\mathrm{x}$ 4). The $\mathrm{MeOH}$ extract was evaporated under reduced pressure till nearly dry $(35 \mathrm{~g}) .10$ $g$ of the dried crude $\mathrm{MeOH}$ extract were chromatographed over silica gel column ( $400 \mathrm{~g}$, $7 \times 120 \mathrm{~cm}$ ). Gradient elution was performed with chloroform/ methanol collecting $50 \mathrm{ml}$ fractions which were separately monitored by TLC. Fractions 20-30 eluted with $\mathrm{CHCl}_{3}$ revealed a single spot $\left(R_{f} 0.42\right.$, system $\left.I\right)$ and acquired positive colour with Dragedorff's; upon repeated purification afforded compound 1 (20 $\mathrm{mg}$ ). Fractions 50-60 eluted with $\mathrm{CHCl}_{3}-\mathrm{MeOH}$ (90:10) afforded a mixture of compounds which was separated to compounds 2 and 3 by preparative TLC; fractions $67-71$ eluted with $\mathrm{CHCl}_{3}-\mathrm{MeOH}(85: 15)$ afforded componds 4 and 5 isolated by preparative TLC, while fractions 92-112 eluted with $\mathrm{CHCl}_{3}-\mathrm{MeOH} \quad(80: 20)$ afforded compound 6 only.

Compound 1: Amorphous powder mp. 106$108^{\circ},[\alpha]_{D}^{20}-2.6(\mathrm{C}=0.1, \mathrm{MeOH}), \mathrm{UV} \lambda_{\max }^{\mathrm{MeOH}}$ nm (log $\epsilon)$ 217(4.37), 222(4.28), 274(4.49).

IR $v_{\max }^{\mathrm{CHCl}_{3}} 3400-3240(\mathrm{NH}), 1655(\alpha, \beta-$ unsaturated amide) and $1605,1595 \mathrm{~cm}^{-1}$ (aromatic ring).

${ }^{1} \mathrm{H}-\mathrm{NMR}\left(\mathrm{CDCl}_{3}\right) \delta 7.76(\mathrm{~d}, \mathrm{~J}=15.5 \mathrm{~Hz}$, $\mathrm{H}-8 "$ ); 6.86 (d, J = $15.5 \mathrm{~Hz}, \mathrm{H}-7 ")$, 6.88-7.48 $(\mathrm{m}$, aryl-H, $10 \mathrm{H}), 2.73-3.48(9 \mathrm{H}, \mathrm{m}), 2.12$ (2H, br.s), 2.08 (3H, s, $\left.\mathrm{CH}_{3} \mathrm{CON}\right), 1.32-1.84$ (8H, m); HRMS, $\mathrm{m} / \mathrm{z}$ (\% rel. int.) 447.2522 (Calc. for $\mathrm{C}_{27} \mathrm{H}_{33} \mathrm{~N}_{3} \mathrm{O}_{3}$ 447.2521) (2), 375.2364 $\left(\mathrm{C}_{24} \mathrm{H}_{27} \mathrm{~N}_{2} \mathrm{O}_{2}\right)$ (3), $316.2028\left(\mathrm{C}_{18} \mathrm{H}_{26} \mathrm{~N}_{3} \mathrm{O}_{2}\right)$ (5), $290.187 \quad\left(\mathrm{C}_{16} \mathrm{H}_{24} \mathrm{~N}_{3} \mathrm{O}_{2}\right) \quad(4), \quad 287.1763$ $\left(\mathrm{C}_{17} \mathrm{H}_{23} \mathrm{~N}_{2} \mathrm{O}_{2}\right)$ (2), $273.1603\left(\mathrm{C}_{16} \mathrm{H}_{21} \mathrm{~N}_{2} \mathrm{O}_{2}\right)$ (2), $260.1502 \quad\left(\mathrm{C}_{15} \mathrm{H}_{20} \mathrm{~N}_{2} \mathrm{O}_{2}\right) \quad(3), \quad 247.1654$ $\left(\mathrm{C}_{14} \mathrm{H}_{19} \mathrm{~N}_{2} \mathrm{O}_{2}\right)$ (5), $231.1444\left(\mathrm{C}_{14} \mathrm{H}_{19} \mathrm{~N}_{2} \mathrm{O}\right)$ (10), $202.1211\left(\mathrm{C}_{13} \mathrm{H}_{16} \mathrm{NO}\right)(5), 200.1077\left(\mathrm{C}_{13} \mathrm{H}_{14} \mathrm{NO}\right)$, $186.0916\left(\mathrm{C}_{12} \mathrm{H}_{12} \mathrm{NO}\right)(4), 174.0915\left(\mathrm{C}_{11} \mathrm{H}_{12} \mathrm{NO}\right)$ (11) and $131.0491\left(\mathrm{C}_{9} \mathrm{H}_{7} \mathrm{O}\right),{ }^{13} \mathrm{C}-\mathrm{NMR}$ are cited in Table 1.
Table 1: ${ }^{13} \mathrm{C}$-NMR Chemical Shifts for Viburnine (22.4 MHz, $\mathrm{CDCl}_{3}$ ).

\begin{tabular}{|c|c|}
\hline $\begin{array}{c}\text { Carbon } \\
\text { No. }\end{array}$ & ppm \\
\hline $\mathrm{C}-2$ & $47.6^{a}$ \\
\hline $\mathrm{C}-3$ & $26.1 / 26.4^{+}$ \\
\hline C-4 & $46.6^{a}$ \\
\hline C-6 & 171.2 \\
\hline C-7 & 31.3 \\
\hline $\mathrm{C}-8$ & $60.4 / 60.8^{+}$ \\
\hline C-10 & $48.2^{\mathrm{a}}$ \\
\hline C-11 & 27.6 \\
\hline C-12 & 28.1 \\
\hline $\mathrm{C}-13$ & $47.2^{\mathrm{a}}$ \\
\hline C-1' & 134.0 \\
\hline C-2', C-6' & $128.1^{b}$ \\
\hline C-3', C-5' & $127.6^{c}$ \\
\hline$C-4^{\prime}$ & $129.5^{\mathrm{d}}$ \\
\hline C-1" & 134.9 \\
\hline C-2", C-6" & $128.2^{b}$ \\
\hline$C-3 ", C-5^{\prime \prime}$ & $127.1^{\mathrm{c}}$ \\
\hline C-4" & $129.8^{d}$ \\
\hline C-7" & 140.7 \\
\hline C-8" & 121.2 \\
\hline C-9" & 167.1 \\
\hline $\mathrm{CH}_{3} \mathrm{CO}$ & $170.1 / 23.4 / 170.7 / 23.3+$ \\
\hline
\end{tabular}

a-d: These assignments are interchangeable.

+ : Doubling of peaks (see discussion).

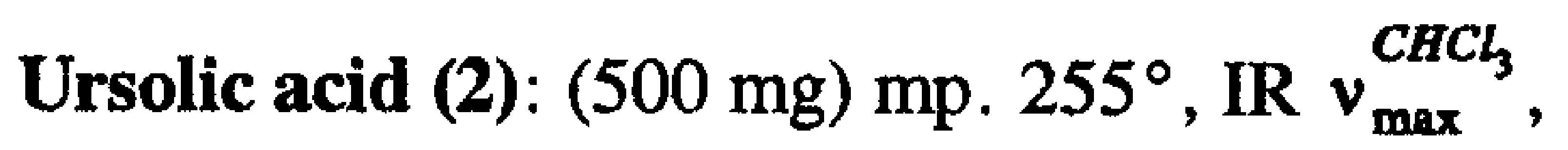
$3400,2600-2300 \mathrm{~cm}^{-1}$ and further confirmation was done with an authentic sample.

Catechin (3): (200 mg), its physical and spectral data are similar with those reported ${ }^{18}$.

Arbutin (4) (300 mg) mp. $200^{\circ}$ and spectral data are identical to those reported ${ }^{8,13}$.

Salicin (5): (1g) identical ( ${ }^{1} \mathrm{H}-\mathrm{NMR}, \mathrm{mp}$ and $\mathrm{mmp}$ ) with an authentic sample. 


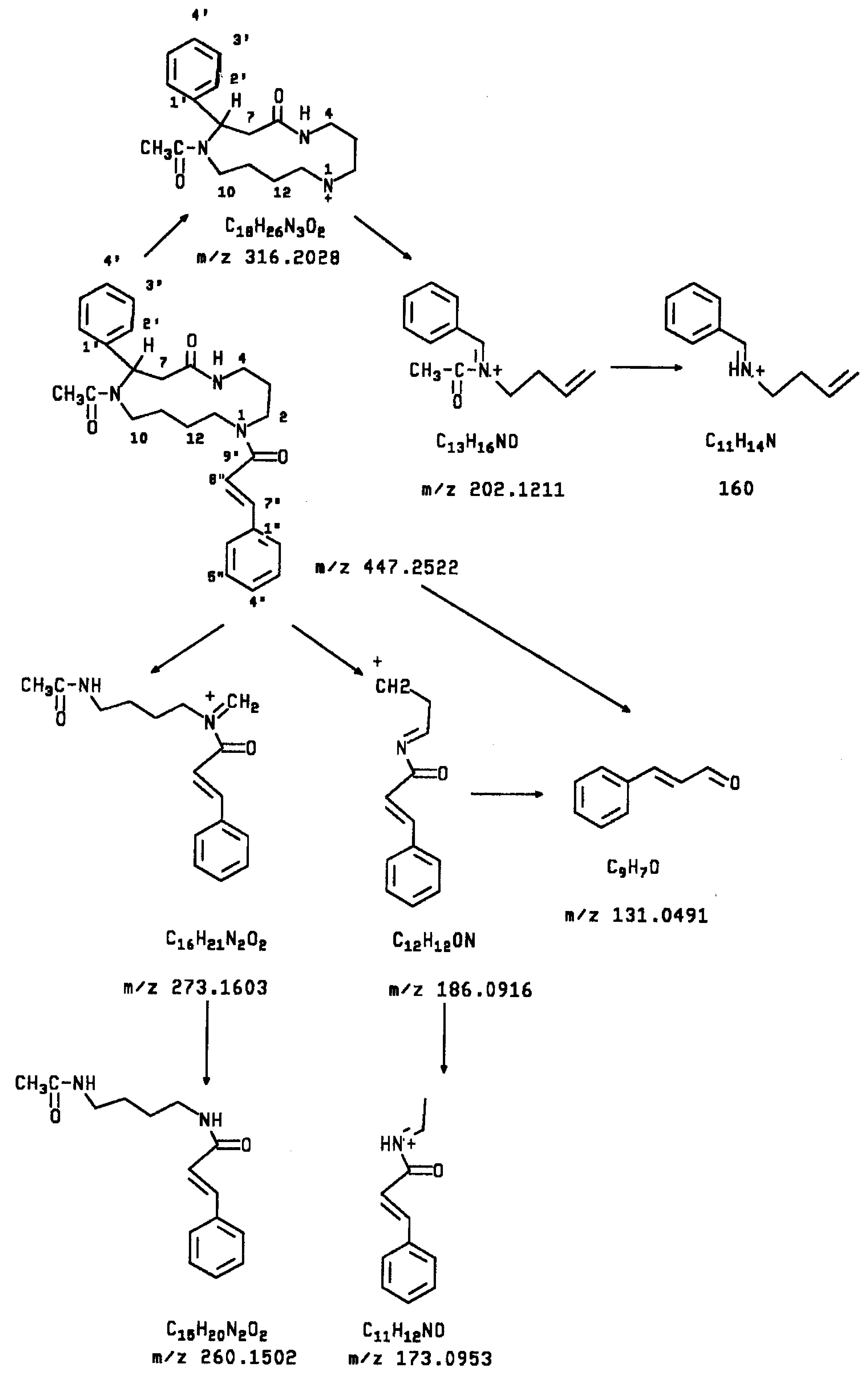

Fig. 1: Possible Fragmentation Pattern of Compound (1) 
Henryoside (6), (20 mg), crystallised from EtOH, mp. $128-130^{\circ},[\alpha]_{D}^{20}-48^{\circ}$ (C 0.4 ; $\mathrm{MeOH})$. The spectral data are identical to those reported $^{9}$.

\section{RESULTS AND DISCUSSION}

The alkaloid under investigation is characterised by the presence of 13-membered ring, represents a new variant of the few known macrocyclic lactam alkaloids derived from spermidine. Detection of viburnine in $V$. rhytidophyllum confirms the fact that these alkaloids do not seem to be of specific occurrence in a particular plant family.

Viburnine: The molecular formula $\mathrm{C}_{27} \mathrm{H}_{33} \mathrm{~N}_{3} \mathrm{O}_{3}$ was determined on the basis of high resolution mass spectrum. The UV spectrum displayed maxima at $217,222 \mathrm{sh}$ and $274 \mathrm{~nm}$; these values are very close to those of celacinnine, a macrocyclic spermidine alkaloid isolated from Maytenus serrata ${ }^{19}$.

The IR spectrum showed broad band at 3340-3240 (NH), 1655 ( $\alpha, \beta$-unsaturated amide) 1605 and $1590 \mathrm{~cm}^{-1}$ (aromatic rings).

The ${ }^{1} \mathrm{H}$-NMR spectrum of [1] showed few distinctive signals, it showed a pair of doublet $(\mathrm{J}=15.5 \mathrm{~Hz})$ at $\delta 7.76$ and 6.86 assigned to the olefinic protons of the trans cinnamic acid residue in addition to signals for two monosubstituted aromatic rings between $\delta$ $7.48 \sim 6.88$. These signals together with ultraviolet absorption bands at $\lambda_{\max }^{\text {MeOH }} 274 \mathrm{~nm}$ suggests the presence of a trans-cinnamyl group $^{19,20}$. The multiplet between $\delta 1.32 \sim 1.84$ $(8 \mathrm{H}, \mathrm{m})$ was assigned to the three methylene groups $\mathrm{CH}_{2}-3, \mathrm{CH}_{2}-12$ and $\mathrm{CH}_{2}-13$, singlet at $\delta$ $2.08\left(3 \mathrm{H}, \mathrm{s}, \mathrm{CH}_{3}-\mathrm{CO}\right)$, broad singlet at $2.12(2 \mathrm{H}$, brs, $\left.\mathrm{CH}_{2}-7\right)$ and multiplet between 2.73-3.48 $(9 \mathrm{H}, \mathrm{m})$ for methylene groups adjacent to nitrogen $\left(\mathrm{CH}_{2}-2,4,10\right.$ and $\left.\mathrm{CH}_{2}-13\right)$ and $\mathrm{CH}-8$ adjacent to nitrogen.

The macrocyclic structure of (1) was ultimately assigned to viburnine on the basis of high resolution mass spectral data and by comparing the ${ }^{13} \mathrm{C}$-NMR spectral data (Table 1) with those of other spermidine alkaloids ${ }^{19,20}$.
The HRMS showed peak at $\mathrm{m} / \mathrm{z} 146$ $\left(\mathrm{C}_{9} \mathrm{H}_{8} \mathrm{NO}\right)$ and a base peak at $\mathrm{m} / \mathrm{z} 131\left(\mathrm{C}_{9} \mathrm{H}_{7} \mathrm{O}\right)$ characteristic for the cinnamyl moiety ${ }^{21}$ and subsequent cleavage of $\mathrm{N}-\mathrm{C}$ bond respectively. Peak at $\mathrm{m} / \mathrm{z} 375\left(\mathrm{M}^{+}-\mathrm{C}_{3} \mathrm{H}_{6} \mathrm{NO}\right)$ attributed to a double cleavage in which the ring amide and either the $C(7)-C(8)$ bond or $C(4)$ methylene groups are lost, provide additional support for the proposed structure. A significant peaks at $\mathrm{m} / \mathrm{z} 316,\left(\mathrm{C}_{18} \mathrm{H}_{26} \mathrm{~N}_{3} \mathrm{O}_{2}\right),\left(\mathrm{M}^{+}-\mathrm{C}_{9} \mathrm{H}_{7} \mathrm{O}\right)$ formed by the cleavage of $\mathrm{N}(1)-\mathrm{C}\left(9^{\prime \prime}\right)$ and $\mathrm{m} / \mathrm{z} 202$ $\left(\mathrm{C}_{13} \mathrm{H}_{16} \mathrm{NO}\right)$ formed by the cleavage of the liable bond $\mathrm{C}(7)-\mathrm{C}(8)$ followed by the $\mathrm{N}(1)-\mathrm{C}(13)$ bond and hydrogen transfer. This fragment gave $\mathrm{m} / \mathrm{z} 160\left(\mathrm{C}_{11} \mathrm{H}_{14} \mathrm{~N}\right)$ through the loss of acetyl group and this confirms structure [1] of viburnine as a celacinnine skeleton but not dihydroperiphylline skeleton ${ }^{21-27}$. The principal fragmentation of the alkaloid is shown in Fig. 1.

The complete set of ${ }^{13} \mathrm{C}-\mathrm{NMR}$ data is compiled in Table $1 .{ }^{1} \mathrm{H}$ and ${ }^{13} \mathrm{C}$-NMR spectra showed doubling of some peaks which may be due to slowly interconverting conformers of the $\mathrm{N}$-acetate; a similar phenomenon has been reported by other authors in amides ${ }^{28-32}$. However, the observed doubling of the signals could also be due to the existence of conformers in solution as a result of the flexibility of the macrocyclic molecule.

\section{Acknowledgement}

We are grateful to Prof. Dr. W. Steglich, Bonn University, Germany, for the spectral analysis.

\section{REFERENCES}

1- C.H.Jarboe, C.M.Schmidt, J.A.Nicholson and K.A.Zirvi, Nature, 212, 837 (1966).

2- C.H.Jarboe, K.A.Zirvi, J.A.Nicholson and C.H.Schmidt, J. Med. Chem., 10, 488 (1967).

3- V.E.Tyler, L.R.Brady and J.E.Robbers, "Pharamcognosy", 9th Ed., Lea \& Febiger; Philadelphia, 75 (1988).

4- L.M.Perry and J.Metzger, "Medicinal Plants of East and Southeast Asia", The 
MIT Press, Cambridge, Massachusetts, and London, England, P. 72 (1980).

5- K.R.Kirtikar and B.D.Basu "Indian Medicinal Plants", Vol. II, P. 1242 (1987).

6- M.Kuroganagi, M.Shiotsu, T.Ebihara, H.Kawai, A.Ueno and S.Fukushime, Chem. Pharm. Bull., 34, 4012 (1986).

7- T. Iwagawa and T.Hase, Phytochemistry, 23, 467 (1984).

8- T.Iwagawa, H.Takahashi, K.Munesada and T.Hase, Phytochemistry, 23, 468 (1984).

9- S.R.Jensen, B.J.Nielsen and V.Norn, Phytochemistry, 18, 904 (1979).

10- T.Iwagawa and T.Hase, Phytochemistry, 22, 225 (1983).

11- T.Hase, T.Iwagawa and K.Munesada, Phytochemistry, 21, 1435 (1982).

12- T.Hase, T.Iwagawa and M.N.Dave, Phytochemistry, 24, 1323 (1985).

13- K.Machida, Y.Nakane and M.Kikuchi, Phytochemistry, 30, 2013 (1991).

14- R.P.Godeau, J.C.Rossi and I.Fouraste, Phytochemisty, 16, 604 (1977).

15- T.Iwagawa and T.Hase, Phytochemistry, 23, 2399 (1984).

16- K.Kawazu, Agric. Biol. Chem., 44, 1367 (1980).

17- K.Machida and M.Kikuchi, Chem. Pharm. Bull., 41, 248 (1993).

18- T.J.Mabry, K.R.Markham and M.B.Thomas, "The Systematic Identification of Flavonoids", Springer, Berlin (1970).

19- S.M.Kupchan, H.P.J.Hintz, R.M.Smith, A.Karim, M.W.Case, W.A.Court and
M.Yatagai, J. Org. Chern. 42, 3660 (1977).

20- S.M.Kupchan, H.P.J.Hintz, R.M.Smith, A.Karim, M.W.Case, W.A.Court and M.Yatagai, J.C.S. Chem. Comm., 329 (1974).

21- H.Pipperger, Phytochemistry, 19, 162 (1980).

22- M.Diaz and H.Pipperger, Phytochemistry, 21, 255 (1982).

23- S.Bashwira and C.Hootele, Tetrahedron, 44 (14), 4521 (1988).

24- T.Kaseda, T.Kikuchi and C.Kibayashi, Tetrahedron Lett. 30 (34), 4539 (1989).

25- R.Hocquemiller, A.Cave and H.P.Husson, Tetrahedron, 33, 645 (1977).

26- S.Lumbu and C.Hootele, J. Nat. Prod., 56, 1418 (1993).

27- A.Guggisberg and M.Hesse, in "The alkaloids" Ed. by A.Brossi, Academic Press, New York, Vol. 22, p. 85-188 (1983).

28- V.U.Ahmad, A.R.Amber, S.Arif, M.H.M.Chem and J.Clardy, Phytochemistry, 24, 2709 (1985).

29- V.U.Ahmad, N.Ismail and A.R.Amber, Phytochemistry, 28, 2493 (1989).

30- V.U.Ahmad, S.Arif, A.R.Amber, M.A.Nasir and K.U.Ghani, Z. Naturforsch., 41b, 1033 (1986).

31- R.O.Von Longoni, N.Viswanathan and M.Hesse, Helv. Chem. Acta., 63, 2119 (1980).

32- W.Voelter, O.Oster and E.Breitmaier, Z.Naturforsch, 28b, 370 (1973). 